\title{
The Hypocrisy of Saudi Arabia
}

\author{
Albertus J. Meintjes \\ Intelligence Fusion, Durham, UK \\ Email: aj.meintjes@gmail.com
}

How to cite this paper: Meintjes, A. J. (2018). The Hypocrisy of Saudi Arabia. Open Journal of Political Science, 8, 433-446. https://doi.org/10.4236/ojps.2018.84028

Received: August 27, 2018

Accepted: October 16, 2018

Published: October 19, 2018

Copyright (C 2018 by author and Scientific Research Publishing Inc. This work is licensed under the Creative Commons Attribution International License (CC BY 4.0).

http://creativecommons.org/licenses/by/4.0/

\begin{abstract}
Saudi Arabia is a traditionally conservative kingdom that has seen rapid changes to domestic and international foreign policy, liberalising their own society while making efforts to tie the Saudi state to Western support. This paper discusses the danger of accepting the Saudi state as a new liberal force and examines the issues that have arisen in the previous year due to Saudi policy, and how these policies may continue in the future.
\end{abstract}

\section{Keywords}

Saudi Arabia, United States, Diplomacy, Security, Foreign Policy, Iran, Iraq

\section{Introduction: The Hypocrisy of Saudi Arabia}

The political situation throughout 2017 in the Middle East has been one mired in realpolitik. State to state the domestic situation varies wildly in terms of domestic policy and stability, as militia groups, sectarianism and rebel groups contribute to the breakdown of stability. However, while international media and reports have been concerned predominantly with the defeat of Daesh, Iran and Syria, other states that are likely to have a far more prominent role in the Middle East in the Future are not only less discussed, but also less understood by many Western academics and decision makers. Saudi Arabia is one such state, a state that is poised to take a leading role in the Middle East as intervention strategy fails and US policy of propping up allies.

As such, this paper's purpose is to briefly examine the current state of Saudi Arabia, henceforth referred to as the Kingdom, and it's rapidly approaching role as a dominant force in the Middle East, particularly in the larger theme of US-Israel relations and Russia, and what major events closing in 2017 will likely form the basis of future policy in 2018. First this piece will briefly examine a timeline of events that have framed the Kingdom as a growing major ally of the US. Next, the diplomatic row concerning Canada will be examined, as a brief 
case study of the hypocrisy that the Kingdom's leaders follow. Thereafter the paper will examine their in surrounding regions that make them a questionable actor to rely on. Specifically, this will include looking at questionable interaction with opposition in Iraq, as well as the shifting regional situation following the defeat of Daesh in the region, the blockade of Qatar and the opaque intervention on Yemen. The goal here is to shine a light on the dealings of the Kingdom, which get relatively little media attention, and form a counter argument for the sudden US backing of a western supported bloc of states in the Middle East.

The evidence points to realism power politics far outweighing any other considerations as power, economy and state survival (self-interest). While there can always be a discussion that can frame actions in different lights, there are major humanitarian concerns in the Kingdom that raise issues pertaining to human security, and the responsibility of states. While use of the Kingdom to strengthen a western alliance in the Middle East, particularly in the face of an emerging bloc headed by Russia, there has never been a good precedent of propping up poor human rights actors to support a western grand strategy. This cold war-esque style strategy frames the hypocrisy of a Saudi alliance with the US. While US foreign policy had been moving towards a more considered approach to human rights in the international community, it is currently focused on playing regional power politics, a dangerous precedent, particularly when an ally of convenience is not fully understood by western decision makers who ignore the potential dangers, or glorify the irrelevant grand gestures of Gulf States. As such, this paper will examine how initial strategic moves by the US to prop up a friendly bloc of states in the Middle East are faltering. Finally, an examination of emerging policies in the last quarter of 2017 will affect 2018.

\section{The Kingdom as a Rising International Actor}

The Kingdom's foreign policy is one that is of major importance today. Major upcoming issues include western relations, Iran, Israel and Qatar. The root of many of the current developments are a result of the growing relations between the US and Saudi. Since the election of Trump, the US has been propping up the Kingdom as a new foundation of a pro-western Middle Eastern alliance. The evidence can be found in the major arms deals with the Kingdom, a state that is clearly both looking to improve their military capacity and become a powerhouse in the region. The 350 billion dollar arms deal over ten years will involve a large influx of advanced western armaments. While there is no specific list of sales, several companies such as Lockheed Martin have made announcements in response to receiving part of the deal. Lockheed Martin did not provide specifics, but their announcement did state that the deal "include(s) integrated air and missile defence systems, multi-mission surface combatant ships, radar systems, surveillance systems, tactical aircraft and rotary wing programs". ${ }^{1}$ This may in-

${ }^{1}$ Martin (2017) Lockheed Martin Plays Major Role In Strengthening United States And Kingdom Of Saudi Arabia Ties To Bolster Global Security" https://news.lockheedmartin.com/2017-05-20-Lockheed-Martin-Plays-Major-Role-In-Strengthening-Uni ted-States-And-Kingdom-Of-Saudi-Arabia-Ties-To-Bolster-Global-Security accessed 1 September 2018. 
dicate a strong commitment to building air superiority in the region. While the reported US-Saudi arms deal has a great deal of controversy, particularly in the wake of a Saudi strike on a Yemenese school bus using US weapons, ${ }^{2}$ a quiet deal saw the opening of a South African weapons factory organised by previous South African president Jacob Zuma, a move that saw very little political attention in South Africa and that involved backdoor politics. ${ }^{3}$

An interesting development is that the traditional western ally in the Middle East, Israel, has proven itself untrustworthy of fostering stability in the Middle East, preferring a hostile, isolationist position under the leadership of the conservative Netanyahu. Despite this shift in support, the US still supports Israeli military superiority in the region, and there are signs of a thawing political relationship between the Kingdom and Israel. Quite recently, Israel proposed a freight train link running through Jordan and connecting to the Kingdom. ${ }^{4}$

Western relations and social media have bypassed Saudi fundamentalism now, as a more vocal kingdom begins to expound on religious rights in light of the Israeli decision to close the $\mathrm{Al}$ Aqsa mosque over security concerns. While each sovereign state has the right to affect policy as long as citizens are protected and provided for, it is strange and hypocritical to find a mention of religious freedom coming to light outside of a highly conservative kingdom. ${ }^{5}$

While it would appear relations are not open as of yet, the US acting as a good office and fostering good will between its emerging allies can only work in the favour of a western backed middle eastern alliance. Further evidence can be found in the softening tone of religious sites in Israel, such as the recent security related events of Haram al-Sharif. ${ }^{6}$ There is clearly a bloc being formed for a pro-western grand strategy. While the US move to mark Jerusalem as the capital of Israel drew ire from Middle Eastern states, aside from an official protest, no further action was taken. Even more suspect is the reports of Yisrael Katz, the Israeli minister of intelligence, inviting Prince Salman for an official visit. ${ }^{7}$ While it's doubtful Prince Salman would visit Israel, lest he draw criticism from popular support in his own country, the lack of any further protest is a sign of closer

\footnotetext{
${ }^{2}$ Elbagir, Abdelaziz, Browne, Arvanitidis, \& Smith-Spark (2018) "Bomb that killed 40 children in Yemen was supplied by the US." $C N N$,

https://edition.cnn.com/2018/08/17/middleeast/us-saudi-yemen-bus-strike-intl/index.html accessed 17 August 2018.

${ }^{3}$ Democratic Alliance (2016) "Saudi Arabia Arms Deal: Government Must Come Clean on Weapons Factory." Democratic Alliance

https://www.da.org.za/2016/04/saudi-arabia-arms-deal-government-must-come-clean-on-weapons -factory/ accessed 3 August 2017.

${ }^{4}$ Lewis (2017) “Israel Proposes Freight Rail Link to Jordan, Saudi Arabia.” Reuters, http://www.reuters.com/article/israel-transportation-jordan-idUSL5N1HD3CX accessed 23 July 2017. ${ }^{5}$ Gazette (2017b) “Saudis Outraged over Al-Aqsa Closure.” Saudi Gazette, http://saudigazette.com.sa/article/513250/SAUDI-ARABIA/Al-Aqsa accessed 25 July 2017. ${ }^{6} \mathrm{BBC}$ (2017b) “Jerusalem: Metal Detectors at Holy Site 'Could Be Removed'." BBC, http://www.bbc.com/news/world-middle-east-40695132 accessed 3 August 2017.

${ }^{7}$ McKernan (2017) "Saudi Crown Prince 'invited to Israel' as Jerusalem Protests Smoulder in West Bank." The Independent,

http://www.independent.co.uk/news/world/middle-east/saudi-arabia-crown-prince-mohammad-bin-s alman-jerusalem-israel-protests-west-bank-us-trump-a8112736.html accessed November 242017.
} 
relations.

An excellent example of the hypocrisy of Saudi Arabia can be in the current spat between the Kingdom and Canada. Despite movements towards liberal values, when Canada critised the Kingdom on imprisoning several activists, including the high profile Hatoon al-Fassi, who protested the male guardianship laws in the Kingdom, the Kingdom responded with overwhelming diplomatic measures, expelling the Canadian ambassador, suspending flights to Toronto and cancelling a long standing foreign student arrangement, which many Saudi students took advantage of. ${ }^{8}$ A surprisingly harsh and vehement response, the Kingdom refused to be critised in its national decision, which is ironic considering the liberal reforms in the Kingdom. However, this sort of response is a classic example of Saudi hypocrisy. The Kingdom may follow through on what can be seen as liberal reforms, but the Kingdom itself and its actors are not liberal reformers, but oligarchs wishing to give the perception of liberal reforms. Whether this is a calculating tactic, or a genuine lack of understanding of liberal values due to culture and history is debatable.

\section{Iraq}

The US and Saudi have a common enemy in the form of Iran. Related to this is the potential flashpoint of Iraq. Iraq has been improving diplomatic relations with Iran throughout 2018 with talks of military and intelligence collusion, ${ }^{9}$ and Iranian backed Militia being given a larger role in anti-Daesh operations less than a week later. ${ }^{10}$ Further evidence of Iran forming closer ties with Iraq also exists in the form of anti-Kurdish action, as seen during the attempt of independence by Kurdistan, a move that failed as regional actors Turkey and Iran quickly shut down trade and access to northern Iraq. ${ }^{11}$ An Iranian ally on a Saudi border is certainly going to be perceived as a security risk, as basic realist theory would show. Saudi has made some interesting decisions in the last few days that could have bearing on such a burgeoning relationship. On the $31^{\text {st }}$ of July, Iraqi political opposition cleric, Moqtada al-Sadr, had an official meeting with the crown prince of the Kingdom, Prince Salman, having been given a special Visa to attend Hajj. During the meeting the prince provided 10 million dollars to al-Sadr to open a Saudi embassy in Najaf, Iraq. ${ }^{12}$ The meeting was also supposed to discuss improving bilateral relations between the two states.

${ }^{8}$ BBC (2018) "Saudi-Canada row: Why Trudeau won't back down." https://www.bbc.com/news/world-us-canada-45102837 accessed 2 September 2018.

${ }^{9}$ Reuters (2017) “Iran and Iraq Sign Accord to Boost Military Cooperation." Reuters, https://www.reuters.com/article/us-iran-iraq-military-idUSKBN1A80HJ accessed 23 July 2017.

${ }^{10}$ The Baghdad Post (2017) “Abadi: IMIS to Participate in Battle for Tal Afar." The Baghdad Post, http://www.thebaghdadpost.com/en/story/14998/Abadi-IMIS-to-participate-in-battle-for-Tal-Afar accessed 29 July 2017.

${ }^{11}$ Meintjes (2017) “The Complications of Kurdish Independence." SCRIPS 8, 1, p.7.

${ }^{12}$ Cusak (2017) "Saudi Arabia Pays Iraqi Shia Cleric Sadr \$10 Million to Set up Consulate in Najaf." Al Araby,

https://www.alaraby.co.uk/english/news/2017/8/2/saudi-arabia-pays-iraqs-shia-cleric-sadr-10-milli on accessed 3 August 2017. 
These dealings create an immediately suspect scenario. Holding official talks with an opposition leader with no position in government is simply not diplomatic procedure, but speaks volumes of Saudi's predisposition towards more traditional interstate relations, not so say anything of paying a private citizen of another state to set up an official diplomatic mission for the KSA. Given the fact that in the same week, on the $4^{\text {th }}$ of August, Sadr called a demonstration against the Iraqi government in Baghdad, ${ }^{13}$ the narrative constructed points to some political backing here. While the demonstrations purpose was to protest electoral law in Iraq, al-Sadr used the platform to call for the disbanding of Iranian backed PMF militia. ${ }^{14}$ Further evidence in this developing relationship can be found in al-Sadr commanding his followers to remove anti-Saudi posters from areas in Iraq. ${ }^{15} \mathrm{Al}$-Sadr pulled his party out of official politics in $2014,{ }^{16}$ but has since acted as a sort of influential figure advocating change outside of official government. Analysts speculated that the move was in line with repositioning his stance and power as early as 2014 rather than quitting politics, ${ }^{17}$ and with the recent elections complete and $\mathrm{Al} \mathrm{Sadr's} \mathrm{party} \mathrm{returning} \mathrm{and} \mathrm{winning} \mathrm{the} \mathrm{majori-}$ ty, allowing him to act as kingmaker in Iraq, the predication has come true.

If Saudi is backing al-Sadr, who has his own military power in the form of "peace companies", ${ }^{18}$ resurgent remnants of the anti US "Mahdi Army" which are a rebranding of a group that is infamous for its part in sectarian violence and death squads, ${ }^{19}$ it is hardly a move that inspires confidence in the objective of Saudi foreign affairs. Official Iranian-Iraqi relations are being formed through official government departments and Prime Minister Abadi himself, and are strengthening ties between the two states. Iranian backed militia in Iraq were instrumental in defeating Daesh and the continued security in the region. Supporting $\mathrm{Al} \mathrm{Sadr}$ prior to the election was a suspect choice considering the democratisation of Iraq, and speaks of Saudi culture operating with a wealthy oligarchy, than official diplomatic channels. It is important to note that in the middle east, with vast differences of religion and culture leading to high tensions,

\footnotetext{
${ }^{13} \mathrm{Al}$ Ghad Press (2017) "Sadr Calls for A 'mass' demonstration in Baghdad and the Provinces on Friday." Al Ghad Press, https://www.alghadpress.com/news/112519/AlghadPress-Article accessed 3 August 2017.

${ }^{14}$ Middle East Eye (2017) "Iraqi Shia cleric Sadr calls on government to disband Iran-backed militia." Middle East Eye,

http://www.middleeasteye.net/news/iraqi-shia-cleric-sadr-calls-government-disband-iran-backedmilitia-849365799 accessed 4 August 2017.

${ }^{15}$ Middle East Monitor (2017) "Iraqi Shia Cleric Orders Removal of Anti-Saudi Posters in His Country." Middle East Monitor,

https://www.middleeastmonitor.com/20170805-iraqi-shia-cleric-orders-removal-of-anti-saudi-post ers-in-his-country/ accessed 5 August 2017.

${ }^{16} \mathrm{BBC}$ (2017a) “Iraq Profile-Timeline." BBC, 2017, http://www.bbc.com/news/world-middle-east-14546763 accessed 5 August 2017.

${ }^{17} \mathrm{NBC}$ News (2014) “Anti-U.S. Cleric Muqtada Al-Sadr Retakes Stage Amid Iraq Turmoil.” NBC News, http://www.nbcnews.com/storyline/iraq-turmoil/anti-u-s-cleric-muqtada-al-sadr-retakes-stage-ami d-n138406 accessed 2 August 2017.

${ }^{18}$ Stanford University (2017) “Mahdi Army." Stanford University, http://web.stanford.edu/group/mappingmilitants/cgi-bin/groups/view/57 accessed 3 August 2017. ${ }^{19} \mathrm{Ibid}$.
} 
supporting sectarian issues under auspices of diplomatic action and political change in the already unstable Iraq, all the more dangerous.

While the political, realist nature of the political games being played in the Middle East are becoming apparent, this is an unfortunate turn. Decisions like backing unofficial political channels with a record of human rights violations are harmful to human security and have become more serious issue in the $21^{\text {st }}$ century. Political theory and history should have displayed to policy makers that opaque diplomatic relations that have no room for oversight lead to incredible disasters for the people. This sort of old diplomacy was common before the great war, when state relations could come down entirely to who knows who within diplomatic circles, where diplomats wield too much power and diplomatic reporting and relations break down, as was the case in the lead up to world war $1 .{ }^{20}$ International diplomacy can no longer come down to favour currying, and while western diplomats and governments have largely learnt from their mistakes, should the Kingdom's contact with opposition in Iraq lead to further strife, Prince Salman, as a primary representative of the Kingdom would ensure the accountability of the Kingdom. It's clear that Saudi, with its full control on media, finds use in out dated strategies, backroom politics and hypocritical declarations, and has little need for the transparent diplomatic ideals of the $20^{\text {th }}$ century. The US seems to be backing an ally of convenience, without considering consequences down the line. An example of this may well be the Qatari crisis.

\section{Qatar}

Gulf States and Egypt agreed to sever all ties with Qatar on the $5^{\text {th }}$ of June, 2017 and produced a list of thirteen demands before any relations were to be re-established. ${ }^{21}$ These run from closing Al-Jazeera and ending relations with Iran to stopping all affiliation with opposition in Gulf States and hand over all files related to such opposition, ${ }^{22}$ another case of hypocrisy, as the Iraq case has shown. Beyond the list of demands, Gulf States stated that Qatar needed to stop supporting terrorism immediately. Again, it is easy to trace all of the Gulf States having some or other connections to the many small mosques and businesses that fund extremist groups, and Saudi itself funds its interest groups.23 Terrorism is a fluid concept that has an entire academic debate surrounding it. As Dexter states, defining terrorism comes with its own list of issues and has spawned its own lists of different types of violence. 24 Here, Saudi seems to be using western terminology used to securitise the Iraq war to separate the groups

\footnotetext{
${ }^{20}$ Otte (2004) "Old Diplomacy: Reflections on the Foreign Office before 1914." Contemporary British History 18, 3, pp. 31-52.

${ }^{21}$ BBC (2017c) "Qatar Crisis: What You Need to Know." BBC, 2017, http://www.bbc.com/news/world-middle-east-40173757 accessed 7 August 2017.

${ }^{22}$ The Associated Press (2017) "List of Demands on Qatar by Saudi Arabia, Other Arab Nations." The Associated Press, https://apnews.com/3a58461737c44ad58047562e48f46e06 accessed 29 July 2017.

${ }^{23}$ BBC (2017c) "Qatar Crisis: What You Need to Know." BBC.

${ }^{24}$ Dexter (2012) “Terrorism and Violence: Another Violence Is Possible?" Critical Studies on Terrorism, 5, 1, pp. 123-124.
} 
they support from the groups Qatar supports.

While the US had some token part in attempting diplomatically resolve the problem, sending their top representative, there was little headway. ${ }^{25}$ The Gulf States backing the anti-Qatar sentiment were remarkably quiet about the situation at the launch of a multi-lateral blockade, a strange precedent for international diplomacy. Regardless, the rationale behind the decision was leaked, as it was discovered that secret treaties signed by all the Gulf States were allegedly broken by Qatar. These secret agreements were meant to avoid misunderstandings regarding the sovereignty of the individual Gulf States. ${ }^{26}$

The above secret rationale points out to a complex political problem in the Middle East, one that western nations should be very careful with getting involved in. As stated, terrorism hardly has a simple definition and the quick work of securitising agents in the US in a post 9/11 world used the term without much academic thought. Overlooking that Saudi funds links to terrorism seems to be a particularly poor precedent for strategic policy. The mire of favouritism and favour currying that is simply a part of Middle Eastern culture that has bled into politics is dangerous, and little understood by western states with the well-established tenants of media freedom and oversight. Forcing Qatar's hand, for example, with little Western response will like push Qatar into the arms of states that the US is attempting to form a bloc against. States that are not a part of this growing alliance are currying favour with an ostracized Qatar, such as Turkey ${ }^{27}$ and $\operatorname{Iran}^{28}$ sending food to the beleaguered state.

\section{Yemen}

Yemen is another challenge when examining the kingdom's foreign policy. While the objective of this paper does not include an in depth analysis of the events leading up to the Saudi intervention, the intervention itself is a familiar one. It isn't difficult to find similarities between previous failed western military interventions in the Middle East where military action stagnated and Saudi's own mission in Yemen, which has been so far unsuccessful. After the failed peaceful transition and the seizure of Western Yemen by pro-Houthi forces, Saudi, amongst other gulf states, has been backing the pro-Hadi government with a predominantly air based campaign, although ground troops were deployed at the beach head in the gulf of Aden to arrest the rebel advance. Western

\footnotetext{
${ }^{25}$ Harris (2017) “Tillerson Comes Up Short in Effort to Resolve Qatar Dispute." NY Times, https://www.nytimes.com/2017/07/13/world/middleeast/qatar-saudi-arabia-rex-tillerson.html accessed 23 July 2017.

${ }^{26}$ Sciutto \& Herb (2017) "Exclusive: The Secret Documents That Help Explain the Qatar Crisis." $C N N$,

http://edition.cnn.com/2017/07/10/politics/secret-documents-qatar-crisis-gulf-saudi/index.html accessed 23 July 2017.

${ }^{27}$ The New Arab (2017) “Turkey Sends First Cargo Ship Filled with Food Supplies to Help Break the Qatari Blockade.” The New Arab,

https://www.alaraby.co.uk/english/news/2017/6/23/turkey-sends-first-ship-load-of-food-to-qatar accessed August 3, 2017.

${ }^{28}$ Reuters (2017) “Iran Flies Food to Qatar amid Concerns of Shortages.” Reuters,

https://www.reuters.com/article/us-gulf-qatar-iran-idUSKBN1920EG?il=0 accessed 3 August 2017.
} 
powers pledged logistical and intelligence support at what was seen was a movement by Iran to support Shia religious groups. ${ }^{29}$

Since then the situation has deteriorated rapidly, with no real solution from the kingdom presented and a near total media blackout on military events in Yemen. The kingdom has done little to alleviate the humanitarian situation in Yemen. While the Saudi government offered compensation for the bombing of a funeral in Sana'a, ${ }^{30}$ an event blamed on poor intelligence, it was only because the bombing was so highly publicised. The war in Yemen has seen outbreaks of both Cholera and Famine. Cholera here is of particular interest, and is a similar case to the funeral bombing. Humanitarian organisations on the ground reported cholera outbreaks as early as October $2016,{ }^{31}$ it was not until a major report by $\mathrm{CNN}$ that uncovered that the Kingdom was censoring free media in the region and published the cholera outbreak on the $22^{\text {nd }}$ of June that the Saudi Crown Prince, Prince Salman changed posture and quickly committed funds to Yemen on the $23^{\text {rd }}$ of June to combat cholera. ${ }^{32}$ The Kingdom, as the leader of the coalition of Arab states intervening in Yemen, has a responsibility to protect the civilians that they are putting at risk with a military intervention. States can simply not base all their actions on petty politics and religious differences while human security is at major risk, as has been the case since the 2001 report by the ICISS, ${ }^{33}$ and the subsequent ratification of the R2P policy by the UN in $2009 .{ }^{34}$

What a scholar and policy maker can take away from the narrative in Yemen is that the Kingdom is not only a state incapable of fulfilling military intervention, a strategic move that has simply not worked before, but is a state that cannot be trusted to fulfill their responsibility to protect civilians. If the kingdom is only willing to assist those in need once the veil has been lifted on their neglect, it may not be a state that is worthy of allying with in the long run. Western democratic states would be hard pressed to defend an ally's humanitarian failures and war crimes if the state in question was simply an ally of strategic convenience and used western weapons and intelligence to further their own designs. Saudi also hosted the Sudanese president Omar al-Bashir for a state visit, ${ }^{35}$ despite the fact that the leader is wanted for war crimes by the ICC. ${ }^{36}$ While Sau-

${ }^{29}$ BBC (2017d) "Yemen Crisis: Who Is Fighting Whom?" $B B C$, http://www.bbc.com/news/world-middle-east-29319423 accessed 29 July 2017.

${ }^{30}$ Gardner (2017) "Yemen Conflict: The View from the Saudi Side." $B B C$, http://www.bbc.com/news/world-middle-east-38239782 accessed 23 July 2017.

${ }^{31}$ Relief Web (2017) “Yemen: Cholera Outbreak-Oct 2016." Relief Web, http://reliefweb.int/disaster/ep-2016-000107-yem accessed 23 July 2017.

${ }^{32}$ Gladstone (2017) "Saudis, at War in Yemen, Give Country \$66.7 Million in Cholera Relief." New York Times,

https://www.nytimes.com/2017/06/23/world/middleeast/yemen-saudi-crown-prince-salman-choler a.html accessed 23 July 2017.

${ }^{33}$ ICISS (2001) The Responsibility to Protect (Ottawa: IDRC).

${ }^{34}$ Secretary-General (2009) "Implementing the Responsibility to Protect, A/63/677, 33, (UN, New York).

${ }^{35}$ Saudi Gazette, a “King Receives Sudanese President.” Saudi Gazette, 2017,

http://saudigazette.com.sa/article/513261/SAUDI-ARABIA/King-Salman accessed 19 July 2017.

${ }^{36}$ The Guardian (2009) "Sudanese President Bashir Charged with Darfur War Crimes." The Guardian, https://www.theguardian.com/world/2009/mar/04/omar-bashir-sudan-president-arrest accessed 23 July 2017. 
di is not a signatory of the Statute of Rome for the ICC, this is still a poor move for a state that is actively trying to make itself more known in international politics and allying with western states. To date, the Saudi foreign policy continues to blockade Yemen, and international media and NGOs continue the struggle to provide aid and valuable information on the humanitarian crisis there.

By examining these case studies, a clear picture of the Kingdom's foreign policy emerges. The Kingdom is clearly trying to become a dominant force in the Gulf, and a main actor in the Middle East. Their careful diplomatic posturing towards Israel and warming ties with the US shows a strategy to become a western backed actor in the Middle East, a worrying thought considering the lack of any real reforms and the continued rule of self-interested Oligarchs. Concerted efforts at armament and military intervention in Yemen build a picture of a nation that aspires to become a regional power player. With no particularly dangerous neighbours and a strong internal security system, the only real rationale for the purchase of sophisticated armaments is to project power. Qatar itself is an interesting case that displays the complexity of regional power politics, and the opaque diplomacy at play at upper levels in the Gulf. Iraq further cements that image by the careful approach to Iraqi power players. Their foreign policy now is seemingly one that aims to build as much of a presence as possible in the Middle East with western backing, while attempting to limit the power and influence of others, particularly Iran.

\section{The Kingdom in 2018}

With the evidence mounting of a regime focused on advancing its own interests through careful manipulation of the facts, how then will the Kingdom react to challenges in 2018 is an important issue. Middle Eastern media and commenters are an interesting source of analytical lenses that are often not considered in Western media. An article by Mustafa Salama, writing on a similar topic on the course of Saudi politics stated that "Saudi Arabia has clearly yielded to American pressure and is publicly beating around the bush when it comes to Israel", 37 a common sentiment throughout the Middle East. Both academics and the population at large are suspicious of US influence in the Middle East, largely due to the military action in the region as well as the historical pro-Israeli support. However, such analysis cast Middle Eastern states in the light of a state that is beholden to US support, and this paper has shown that the Kingdom, while certainly ingratiating itself towards Western sentiment by instituting increasingly liberal policies, is using the leeway then given by the US to fulfil its own foreign policy goals.

As such, the common sentiment of US meddling and control in the Middle East may well be an out-dated concept, as the Kingdom makes it's increasingly

${ }^{37}$ Salama (2017) “Mohammed Bin Salman's Reforms Can't Disguise the Grim Saudi Reality.” Middle East Eye,

http://www.middleeasteye.net/columns/how-saudi-arabia-shooting-itself-foot-378177986 accessed 10 November 2017. 
important towards a cohesive US foreign policy in the Middle East. While states in the Middle East, such as Iraq, lean towards increasingly conservative measures to impose what conservative politicians would call a legitimate Islamic state, putting into effect a ban on alcohol ${ }^{38}$ and opening a discussion to legitimise child marriage, ${ }^{39}$ major power players in the Kingdom, namely Prince Salman, drifts away to use the goodwill to impose its own religious and political will on surrounding states.

Another rationale behind Saudi continuing this policy is the pursuit of nuclear deals with the West. The Kingdom has made overtures towards the west, seeking nuclear power as a means of diversifying their power infrastructure in the region. ${ }^{40}$ While this may be a move to pursue the new economic vision of the kingdom, and an attempt to move away from traditional oil based economy in the face of a market that drifts towards alternate power sources in the US and Europe, with both Israel and Iran holding some form of nuclear power, this may be the first glimpse of a more assertive Saudi Arabia attempting to enter the world of nuclear politics. With Israel seen as a less valuable strategic partner in the complex world of Middle East politics, it is a rationale move for the Kingdom to fill a new role as a strong Islamic partner for the US in the Middle East, an idea all the more valuable in the face of increasing Russian involvement and closer Iraq-Iran relations.

A final valuable point to note for 2018 is the role of Prince Salman in both domestic and international politics. As stated earlier, Prince Salman has made a habit of poor international policy decisions, and seems to be positioning himself as the leader of Saudi in all but name. His decision to eliminate any potential competition in the anti-corruption operations on the $4^{\text {th }}$ of November by arresting major Saudi individuals that pose a threat to his rise, from those with significant financial power to others who control the media, such as Walid bin Talal. ${ }^{41}$ Little has been seen from King Abdullah in recent months, with Prince Salman's proclamations and actions usually taking the forefront of Saudi policy. The Prince is without a doubt the current de facto ruler of the Kingdom, and has clearly set himself up that way.

Since his rise to power and the subsequent arrests and profits poured into the Kingdom my large fines imposed on the arrested Princes, Prince Salman has continued to sell a softer side of himself, with the lifting of the ban on female ${ }^{38}$ Osborne (2017) “Iraq Parliament Bans Alcohol in Surprise Vote.” The Independent, http://www.independent.co.uk/news/world/middle-east/iraq-alcohol-ban-baghdad-parliament-isla m-a7376216.html accessed 20 November 2017.

${ }^{39} \mathrm{Al}$ Araby (2017) "Iraq Withdraws Controversial 'Child Marriage Law." Al Araby, https://www.alaraby.co.uk/english/news/2017/11/23/iraq-withdraws-controversial-child-marriage-1 aw accessed 24 November 2017.

${ }^{40}$ The Baghdad Post (2017) "Saudi Arabia Hopes to Start Nuclear Pact Talks with U.S. in Weeks." The Baghdad Post, accessed December 21, 2017, http://www.thebaghdadpost.com/en/story/21271/Saudi-Arabia-hopes-to-start-nuclear-pact-talks-w ith-U-S-in-weeks.

${ }^{41} \mathrm{Al}$ Rasheed (2017) “The Night of the Long Knives in Saudi Arabia.” Middel East Eye, http://www.middleeasteye.net/columns/night-long-knives-saudi-arabia-1884539620 accessed 8 November 2017. 
drivers being seen as a major step. The ban itself was a poorly veiled attempt to maintain extreme conservative values. With no logical rationale to use, conservative religious leaders would quote false scientific facts to continue the policy, such as driving a vehicle is dangerous to a woman's reproductive organs. It is important to note that the policy was a continuation of the conservative masculine dominance in the Kingdom, and allowing women to drive was only a small issue in the religiously conservative society. Women in the Kingdom still require a male guardian to complete a majority of tasks, and while a woman may now legally drive, she technically cannot go anywhere without her male guardian's authorization. ${ }^{42}$ The issue of male guardianship itself is still a protected concept in the Kingdom, with activists regularly arrested for speaking out. The issue of lifting male guardianship is a direct threat to the pride and power of men in the Kingdom, and as such is a far more divisive issue than driving. As the spat between Canada and the Kingdom have shown, daring to criticize and threaten the male leaders of the Kingdom is still subject to a large backlash, and those hopeful for a social shift in the Kingdom will likely be disappointed.

\section{Conclusion}

In summation, the Kingdom is a complex state that is shifting domestically and internationally. However, the conservative kingdom is still a hard-line monarchy based on an authoritarian regime that does not seem to have the responsibility to handle questions of ethics and human rights. US policy in pursuing self-interest has left terrible chaos and discord in the past, enabling regional military hegemons with the power to suppress their own, and neighbouring states' populations. In fact, states such as Iraq and Afghanistan are still embroiled in major conflict, and with Iraq and Iran relations warming up in the face of Daesh, ${ }^{43}$ yet another threat emerges for Western interests.

Propping up another local power is likely to only increase regional instability. With the situation in Yemen deteriorating, sectarian mandates advancing, and back room cut throat politics and favour currying among Gulf States, it is difficult to see why the US would deem it wise to push an agenda in the Middle East by propping up an ultra-conservative authoritarian state. Beyond fulfilling a presidential campaign promise by president trump, and placing the burden of US caused conflict in the Middle East at the feet of regional actors, the only other result may well be the further deterioration of human security in the region. Moving into 2018, observers should expect continued policies cracking down on conservative measures, while new liberal policies are made to show Saudi in a more favourable light. However, one should not mistake the setting up of cine-

\footnotetext{
${ }^{42}$ Wurscher (2018) "Women in Saudi Arabia Granted the Right to Drive: A Step Away from Male Guardianship Laws?” Michigan State University: College of Law,

https://www.msuilr.org/msuilr-legalforum-blogs/2018/1/22/women-in-saudi-arabia-granted-the-rig ht-to-drive-a-step-away-from-male-guardianship-laws accessed 25 June 2018.

${ }^{43}$ Reuters (2017) "Iran and Iraq Sign Accord to Boost Military Cooperation." Reuters,

https://www.reuters.com/article/us-iran-iraq-military-idUSKBN1A80HJ accessed 23 July 2017.
} 
mas and free red sea resorts as a sign of a legitimising state actor.

Readers of this paper would surely notice the lack of any significant focus on oil, a subject is often synonymous with the Kingdom. But the intention here was to look at policy decisions and a transforming Kingdom through a lens excluding the classical realist notion of oil based politics.

Each step of this paper ultimately had the purpose of establishing the conservative, traditional style of foreign policy that the Kingdom follows. The title of this paper, The Hypocrisy of Saudi Arabia, is not meant as an insult, but to preach caution to those who watch the policy changes in the Kingdom. The Kingdom is not a sudden liberal anomaly that focuses on the rights of the people. It is still a realist state actor, with the added complexity of an absolute monarchy at the helm. The hypocrisy is meant to shine a light on the dealings of Saudi Arabia and for those who wish to deal with the Kingdom to remember that the Kingdom is led by oligarchs, not champions of the people, a fact easy to understand when examining the diplomatic row concerning Canada as mentioned earlier. The emerging liberal policies and growing support with the West are events that should be watched with suspicion and caution rather that elation. Continuing elitist policies and sectarian spread are likely to continue in the future, and in the wake of increasing Israeli tension and shifting alliances in the region, The Kingdom is a state to watch closely.

\section{Conflicts of Interest}

The author declares no conflicts of interest regarding the publication of this paper.

\section{References}

Al Araby (2017). Iraq Withdraws Controversial "Child Marriage Law". https://www.alaraby.co.uk/english/news/2017/11/23/iraq-withdraws-controversial-chil d-marriage-law

Al Ghad Press (2017). Sadr Calls for A "Mass" Demonstration in Baghdad and the Provinces on Friday.

https://www.alghadpress.com/news/112519/AlghadPress-Article

Al Rasheed, M. (2017). The Night of the Long Knives in Saudi Arabia. Middel East Eye. http://www.middleeasteye.net/columns/night-long-knives-saudi-arabia-1884539620

BBC (2017a). Iraq Profile-Timeline.

http://www.bbc.com/news/world-middle-east-14546763

BBC (2017b). Jerusalem: Metal Detectors at Holy Site “Could Be Removed”. http://www.bbc.com/news/world-middle-east-40695132

BBC (2017c). Qatar Crisis: What You Need to Know-BBC News. http://www.bbc.com/news/world-middle-east-40173757

BBC (2017d). Yemen Crisis: Who Is Fighting Whom?

http://www.bbc.com/news/world-middle-east-29319423

BBC (2018). Saudi-Canada Row: Why Trudeau Won't Back Down. https://www.bbc.com/news/world-us-canada-45102837

Cusak, R. (2017). Saudi Arabia Pays Iraqi Shia Cleric Sadr $\$ 10$ Million to Set up Consu- 
late in Najaf.

https://www.alaraby.co.uk/english/news/2017/8/2/saudi-arabia-pays-iraqs-shia-cleric-s adr-10-million

Democratic Alliance (2016). Saudi Arabia Arms Deal: Government Must Come Clean on Weapons Factory.

https://www.da.org.za/2016/04/saudi-arabia-arms-deal-government-must-come-cleanon-weapons-factory/

Dexter, H. (2012). Terrorism and Violence: Another Violence Is Possible? Critical Studies on Terrorism, 5, 121-137. https://doi.org/10.1080/17539153.2012.659920

Elbagir, N., Abdelaziz, S., Browne, R., Arvanitidis, B., \& Smith-Spark, L. (2018). Bomb That Killed 40 Children in Yemen Was Supplied by the US. CNN.

https://edition.cnn.com/2018/08/17/middleeast/us-saudi-yemen-bus-strike-intl/index. html

Gardner, F. (2017). Yemen Conflict: The View from the Saudi Side. http://www.bbc.com/news/world-middle-east-38239782

Gladstone, R. (2017). Saudis, at War in Yemen, Give Country \$66.7 Million in Cholera Relief. New York Times.

https://www.nytimes.com/2017/06/23/world/middleeast/yemen-saudi-crown-prince-sa lman-cholera.html

Harris, G. (2017). Tillerson Comes up Short in Effort to Resolve Qatar Dispute. NY Times.

https://www.nytimes.com/2017/07/13/world/middleeast/qatar-saudi-arabia-rex-tillerso n.html

ICISS (2001). The Responsibility to Protect. Ottawa: IDRC.

Lewis, O. (2017). Israel Proposes Freight Rail Link to Jordan, Saudi Arabia. Reuters. http://www.reuters.com/article/israel-transportation-jordan-idUSL5N1HD3CX

Martin, L. (2017). Lockheed Martin Plays Major Role in Strengthening United States and Kingdom of Saudi Arabia Ties to Bolster Global Security. https://news.lockheedmartin.com/2017-05-20-Lockheed-Martin-Plays-Major-Role-InStrengthening-United-States-And-Kingdom-Of-Saudi-Arabia-Ties-To-Bolster-Global-Security

McKernan, B. (2017). Saudi Crown Prince "Invited to Israel" as Jerusalem Protests Smoulder in West Bank. The Independent. http://www.independent.co.uk/news/world/middle-east/saudi-arabia-crown-prince-m ohammad-bin-salman-jerusalem-israel-protests-west-bank-us-trump-a8112736.html

Meintjes, A. J. (2017). The Complications of Kurdish Independence. SCRIPS, 8, 1-11.

Middle East Eye (2017). Iraqi Shia Cleric Sadr Calls on Government to Disband Iran-Backed Militia.

http://www.middleeasteye.net/news/iraqi-shia-cleric-sadr-calls-government-disband-ir an-backed-militia-849365799

Middle East Monitor (2017). Iraqi Shia Cleric Orders Removal of Anti-Saudi Posters in His Country.

https://www.middleeastmonitor.com/20170805-iraqi-shia-cleric-orders-removal-of-ant i-saudi-posters-in-his-country/

NBC News (2014). Anti-U.S. Cleric Muqtada Al-Sadr Retakes Stage Amid Iraq Turmoil. http://www.nbcnews.com/storyline/iraq-turmoil/anti-u-s-cleric-muqtada-al-sadr-retak es-stage-amid-n138406

Osborne, S. (2017). Iraq Parliament Bans Alcohol in Surprise Vote. The Independent. 
http://www.independent.co.uk/news/world/middle-east/iraq-alcohol-ban-baghdad-par liament-islam-a7376216.html

Otte, T. G. (2004). Old Diplomacy: Reflections on the Foreign Office before 1914. Contemporary British History, 3, 31-52.

Relief Web (2017). Yemen: Cholera Outbreak Oct. 2016. http://reliefweb.int/disaster/ep-2016-000107-yem

Reuters (2017). Iran and Iraq Sign Accord to Boost Military Cooperation. https://www.reuters.com/article/us-iran-iraq-military-idUSKBN1A80HJ

Reuters (2017). Iran Flies Food to Qatar amid Concerns of Shortages. https://www.reuters.com/article/us-gulf-qatar-iran-idUSKBN1920EG?il=0

Salama, M. (2017). Mohammed Bin Salman's Reforms Can't Disguise the Grim Saudi Reality. Middle East Eye.

http://www.middleeasteye.net/columns/how-saudi-arabia-shooting-itself-foot-3781779 $\underline{86}$

Saudi Gazette (2017a). King Receives Sudanese President. http://saudigazette.com.sa/article/513261/SAUDI-ARABIA/King-Salman

Saudi Gazette (2017b). Saudis Outraged over Al-Aqsa Closure. http://saudigazette.com.sa/article/513250/SAUDI-ARABIA/Al-Aqsa

Sciutto, J., \& Herb, J. (2017). Exclusive: The Secret Documents That Help Explain the Qatar Crisis. CNN.

http://edition.cnn.com/2017/07/10/politics/secret-documents-qatar-crisis-gulf-saudi/in dex.html

Secretary-General (2009). Implementing the Responsibility to Protect. A/63/677, 33, New York.

Stanford University (2017). Mahdi Army. http://web.stanford.edu/group/mappingmilitants/cgi-bin/groups/view/57

The Associated Press (2017). List of Demands on Qatar by Saudi Arabia, Other Arab Nations. https://apnews.com/3a58461737c44ad58047562e48f46e06

The Baghdad Post (2017). Abadi: IMIS to Participate in Battle for Tal Afar. http://www.thebaghdadpost.com/en/story/14998/Abadi-IMIS-to-participate-in-battle-f or-Tal-Afar

The Baghdad Post (2017). Saudi Arabia Hopes to Start Nuclear Pact Talks with U.S. in Weeks.

http://www.thebaghdadpost.com/en/story/21271/Saudi-Arabia-hopes-to-start-nuclearpact-talks-with-U-S-in-weeks

The Guardian (2009). Sudanese President Bashir Charged with Darfur War Crimes. https://www.theguardian.com/world/2009/mar/04/omar-bashir-sudan-president-arrest

The New Arab (2017). Turkey Sends First Cargo Ship Filled with Food Supplies to Help Break the Qatari Blockade.

https://www.alaraby.co.uk/english/news/2017/6/23/turkey-sends-first-ship-load-of-foo d-to-qatar

Wurscher, I. (2018). Women in Saudi Arabia Granted the Right to Drive: A Step Away from Male Guardianship Laws? Michigan State University: College of Law. https://www.msuilr.org/msuilr-legalforum-blogs/2018/1/22/women-in-saudi-arabia-gr anted-the-right-to-drive-a-step-away-from-male-guardianship-laws 